ELORE (ISSN 1456-3010), vol. 19 - 1/2012.

Julkaisija: Suomen Kansantietouden Tutkijain Seura ry.

[http://www.elore.fi/arkisto/1_12/aula.pdf]

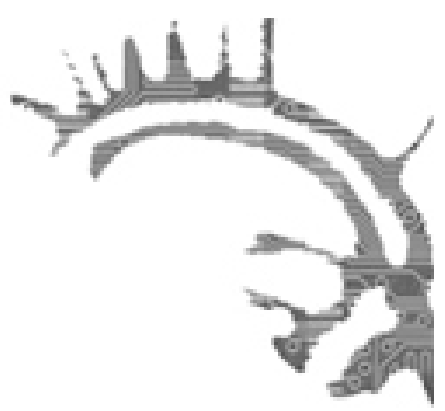

KIRJA-ARVIO

\title{
YLEISESITYS FENOMENOLOGISESTA FILOSOFIASTA
}

MIETTINEN, TIMO \& PULKKINEN, SIMO \& TAIPALE, JOONA (toim.) 2010: Fenomenologian ydinkysymyksiä. Helsinki: Gaudeamus. 277 sivua.

Inkeri Aula

Mielenkiinto fenomenologisia lähestymistapoja kohtaan on kulttuuritieteissä jatkuvasti kasvanut. Aiemman uskontofenomenologian ja etnometodologioiden lisäksi etenkin aistihavaintojen ja ruumiinfenomenologian näkökulmat ovat saaneet tilaa hyvin moninaisten kulttuurin ilmiöiden tutkimuksessa, kun on tutkittu toimijoiden kokemuksia ja reflektoitu erilaisia tietämisen ja tuntemisen tapoja (mm. Tiili 2011; Knibbe \& Versteeg 2008). Myös akateemisen filosofian piirissä fenomenologialla on Suomessa merkittävä asema. Tästä suosiosta huolimatta syksyllä 2010 julkaistu artikkelikokoelma Fenomenologian ydinkysymyksiä on toistaiseksi ainoa suomeksi julkaistu johdantotyyppinen teos fenomenologisesta filosofiasta.

Fenomenologialla on runsaasti erityistieteellisiä sovelluksia, mutta tässä muuten monipuolisessa artikkelikokoelmassa yhtymäkohdat esimerkiksi antropologiaan, kulttuurintutkimukseen ja etnografisiin metodeihin loistavat poissaolollaan. Kokonaiskuva fenomenologian mahdollisuuksista jää sikäli vajaaksi. Filosofian kannalta aihetta luotaava artikkelikokoelma on kuitenkin varsin kattava ja selkeästi esitetty johdatus 
Inkeri Aula: Yleisesitys fenomenologisesta filosofiasta

fenomenologiseen filosofiaan tradition sisältä käsin tarkasteltuna ja on sellaisena mielenkiintoinen myös kulttuurintutkijoille. Kirjassa tuodaan vahvasti esiin yhteisöllisyyden ja kulttuuris-historiallisen kontingenssin keskeisyyttä fenomenologiselle filosofialle, mikä lähentää sitä kulttuuritieteisiin.

\section{FENOMENOLOGIA TIETEENÄ - IRTI SUBJEKTIIVISEN IDEALISMIN SYYTÖKSISTÄ}

Johdannossa kirjan toimittajat esittelevät fenomenologian luonnetta filosofisena asenteena, joka pyrkii yhä uudelleen palaamaan ajattelun lähtökohtiin. Fenomenologia ymmärretään tieteenalaksi, joka tutkii eletyn todellisuuden ilmiöitä (fainomena) ja niiden käsitteellistä jäsentämistä (logos). Se pyrkii kuvailemaan kokemuksen yleisiä rakenteita jäsentämällä filosofisesti, miten todellisuus koetaan moninaisissa suhteissa maailmaan. Kautta kirjan korostetaankin, että sosiaalisen todellisuuden rakentumista voidaan lähestyä fenomenologisesti vastineena filosofiassa usein toistetulle kritiikille kokemuksen mahdollisuusehtojen reflektoinnin liiallisesta subjektisidonnaisuudesta.

Fenomenologian ydinkysymyksiä on jaettu neljään temaattiseen osioon. "Menetelmä"osio keskittyy alan patriarkkojen, Edmund Husserlin ja Martin Heideggerin kysymyksenasetteluihin sekä fenomenologian ja luonnontieteen suhteeseen. Husserlin fenomenologiahan pyrki löytämään filosofialle uudelleen paikan ensimmäisenä tieteenä suhteessa empiirisiin tieteisiin. Tämän Husserl teki tutkimalla kantilaisittain kokemuksen mahdollisuusehtoja. Simo Pulkkinen käy artikkelissaan läpi Husserlin menetelmän peruskäsitteet. Reduktio on se fenomenologinen asenne, jossa filosofi pyrkii irtautumaan naturalistisesta havainnointitavastaan, totunnaisesta tavasta havaita asiat jo opitusti jäsentyneinä. Näin Husserl pyrki löytämään kokemuksessa annetun todellisuuden yleisimmän tason mielekkyysrakenteen, eidokset, joina maailma meille ilmenee. Etnografin kannalta reduktiota voisi pohtia myös mahdollisena osallistuvan havainnoinnin tyylinä, metodina kohti toiseuden ymmärtämistä.

Heideggerin kriittisiä tulkintoja esitellään muun muassa Jussi Backmanin artikkelissa. Husserlin eideettisen reduktion Heidegger tuomitsee idealismina, jonka löytämät yleiset, olemukselliset mielekkyysrakenteet ovat mahdottomia perustella, sillä mielekkyys on aina tilanne- ja kontekstisidonnaista. Fenomenologiasta tulee hermeneutiikkaa, konkreettisten mielekkyystilanteiden kielellistä tulkintaa. Heideggerin fenomenologia kielellis-käsitteellisenä konstruktiona lähentelee toisinaan jopa runollista luovuutta - ja etnografista kirjoittamista.

\section{INTERSUBJEKTIIVISUUS JA YHTEISÖ FENOMENOLOGISESSA FILOSOFIASSA}

Kirjan toisessa osiossa, "Persoona", käsitellään minuutta ja intersubjektiivisuutta sekä Husserlin varhaisemmassa ja myöhäisemmässä tuotannossa että Maurice Merleau-Pontyn 
Inkeri Aula: Yleisesitys fenomenologisesta filosofiasta

ruumiillisen subjektin käsitteessä. Erityisesti Joona Taipaleen artikkeli "Intersubjektiivisuus ja normaalius" tarjoaa kiinnostavan näköalan Husserlin ajattelussa vähemmän huomioituun intersubjektiivisuuden perustavuuteen kaikelle kokemukselle. MerleauPontyn ruumiinfenomenologia taas on kiinnostanut kulttuurintutkijoita paitsi keinona tarkastella havainnon ja kokemuksen merkityksiä ihmisen suhteessa maailmaan, myös keinona arvioida kriittisesti tutkijan roolia. Fenomenologinen asenne vie tutkijan olemisen, tietämisen ja kokemisen tapojen reflektointiin myös suhteessa tutkittavien vastaaviin.

Kirjan kolmannessa, "Yhteisö"-nimisessä osiossa Backmanin avaamaa Heideggerin Husserl-kritiikkiä täydentää Susanna Lindbergin artikkeli. Tämä yksi kirjan kiinnostavimmista artikkeleista tarjoaa katsauksen "tapaus Heideggeria" kritisoineiden ja eteenpäin vieneiden ranskalaisfilosofien ajatteluun. Osiossa pohditaan fenomenologian naturalistiseen asenteeseen ja positivistisiin yhteiskuntanäkemyksiin kohdistamaa kritiikkiä, suhdetta mannermaiseen poliittiseen filosofiaan ja (filosofin) yhteisöllistä vastuuta Hannah Arendtin ajattelussa. Artikkelissa "Ranskalainen keskustelu Heideggerin 'alkuperäisestä etiikasta' ja politiikasta" Lindberg raottaa Heideggerin natsiyhteyksien kirvoittamaa kritiikkiä fenomenologisen ajattelun mahdollisista yhteyksistä totalitarismiin. Monet kriitikot (esim. Beaufret, Lacoue-Labarthe, Taminiaux) näyttävät päätyvän pessimistisiin arvioihin Heideggerin ontologiaa lähentelevän alkuperäisen etiikan mahdollisuuksista käytännöllisen yhteisöelämän tai poliittisen etiikan alueella. Jean-Luc Nancy puolestaan on jatkanut Heideggerin vähemmälle huomiolle jättämän kanssaolemisen käsitteen kehittämistä muodostaessaan oman "ainutkertaisen moninaisen olemassaolon" filosofiansa, jossa oleminen nähdään aina useamman olevan välisenä tapahtumisena - mihin sopisi lisätä: siis kulttuurisena. Martina Reuterin artikkeli Hannah Arendtin vastuun filosofiasta täydentää erinomaisesti käytännöllisen yhteiskunnallisen toiminnan mahdollisuuksien fenomenologista arviointia. Arendt korostaa etenkin julkisen tilan merkitystä poliittiselle toimijuudelle.

Kirjan päätteeksi "Yhteyksiä"-osiossa reflektoidaan ansiokkaasti fenomenologian yhteyksiä lähialueilleen Simone de Beauvoirin eksistentialistisen naisen tilan pohdintojen, Henri Bergsonin naurun ja amerikkalaisten pragmatistien kautta. Näistä muun muassa viimeksi mainitut ovat vaikuttaneet merkittävästi myös kulttuurintutkimuksen tulkinnalliseen perinteeseen. Kai Alhanen esittelee Henri Bergsonia sekä varhaisena fenomenologina, joka oli jo löytänyt fenomenologian keskeiset teemat - välittömän kokemuksen, tietoisuuden virran ajallisuuden ja konkreettisissa tilanteissa muodostuvan vapauden - että fenomenologian kriitikkojen innoittajana Nauru-teoksen komiikan filosofian kautta. Bergsonin ajatukset maailmankaikkeuden ja kokemuksen redusoimattomasta moneudesta asettuvat olemuksellisen, ilmiötodellisuuden olemuksia loputtomasti etsivän, fenomenologian husserlilaista perinnettä vastaan. Juuri huumori herättää meidät vastustamaan muuttuvaisen ja joustavan yhteisöelämän keinotekoista jäykistämistä. Pragmatistinen traditio jakaa saman antinaturalistisen vireen, jossa elämä ei ole rakenteiden vanki ja kuten fenomenologit voivat myöntää, tietoteoreettisen ajattelun on jatkuvasti voitava kyseenalaistaa omat lähtökohtansa ja suuntauduttava käytännön elämään. 
Inkeri Aula: Yleisesitys fenomenologisesta filosofiasta

\section{FENOMENOLOGISEN FILOSOFIAN YDINKYSYMYKSET KULTTUURINTUTKIMUKSESSA}

Valtaosa artikkelikokoelman kirjoittajakunnasta, joka koostuu pääosin nuorista tutkijoista ja lehtoreista, korostaa sitä, kuinka filosofinen fenomenologia huomioi ajallis-paikallisten tekijöiden merkityksen kokevan subjektin suhteessa elämismaailmaansa sekä toisiin kokijoihin: aistihavainnot ovat historiallisesti ja yhteisöllisesti normittuneita. Kielellisen käänteen jälkeen tämä huomio ei liene juuri hätkähdyttänyt kulttuurintutkijoita, joita fenomenologian perinne on alkanut kiehtoa pikemminkin ruumiillis-aistimellisen kokemuksen tutkimisen välineenä.

Siirtymä kulttuurin rakenteiden tarkastelusta prosessuaaliseen kulttuurikäsitykseen liittyy osaltaan fenomenologian suosion kasvuun, kun eletty kokemus nousee yhä perustellummin tutkimuksen huomiopisteeseen. Toisaalta se on oire epäonnisen kulttuurin teksti-metaforan umpikujasta (ks. myös Rantala 2010). Juuri siksi on hyvä muistaa tekstilähtöisen hermeneutiikan ja fenomenologian yhteiset juuret. Ymmärrykseen pyrkiville tieteenaloille, diltheyläisittäin ihmistieteille ylipäänsä on ollut olennaista inhimillisen olemisen intentionaalisuuden osoittaminen: tietoisuus suuntautuu aina kohti maailmaa ja konstituoituu tässä suhteessa, eikä se siten ole redusoitavissa kausaalisiin selityksiin. Tekstuaalisen kulttuurikäsitteen pääsyyllinen Clifford Geertzkään ei epistemologisesti ole kaukana fenomenologiasta. Esimerkiksi argumentoidessaan brain-mind-culture-erottelua vastaan Geertz vetoaa neurologiseen ja arkeologiseen tietoon osoittaakseen biologisen, psykologisen ja sosiokulttuurisen keskinäisriippuvaisen ja toisiaan konstituoivan luonteen ja toteaa yksinkertaisesti: "Our brains are not in a vat, but in our bodies. Our minds are not in our bodies, but in the world. And as for the world, it is not in our brains, our bodies, or our minds: they are, along with gods, verbs, rocks, and politics, in it." (Geertz 2000, 205-206).

Filosofisesti Fenomenologian ydinkysymyksiä on epätasaisuudestaan huolimatta - tai sen vuoksi - varsin kattava johdantoteos, jonka lyhyet ja selkeästi kirjoitetut artikkelit ovat helposti lähestyttäviä. Embodiment-käsitteen sekavaa käyttöä tai uskontofenomenologian nykytilaa pohtivalle kulttuurintutkijalle kirja ei kuitenkaan tarjoa tienviittoja. Suomenkielinen yleisteos fenomenologisen kulttuurintutkimuksen ydinkysymyksistä onkin yhä kirjoittamatta.

\section{KirjallisuUs}

GEERTZ, CLIFFORD 2000: Available Light. Anthropological Reflections on Philosophical Topics. Princeton: Princeton University Press.

KNIBBE, KIM \& VERSTEEG, PETER 2008: Assessing Phenomenology in Anthropology. - Critique of Antbropology 28(1).

RANTALA, JANNE JUHANA 2010: Antropologi oom-ringissä. Aistihavainto kenttätyössä. - Pöysä, Jyrki \& Järviluoma, Helmi \& Vakimo, Sinikka (toim.), Vaeltavat metodit. Joensuu: Suomen Kansantietouden Tutkijain Seura. 
Inkeri Aula: Yleisesitys fenomenologisesta filosofiasta

TIILI, MIIA-LEENA 2011: Läsnäoloa ja refleksiivisyyttä . Ammattikulttuurin tutkimus Merleau-Pontyn fenomenologian valossa . - Elore 18(2). [online]. <http:// www.elore.fi/arkisto/2_11/tiili.pdf> [1.3.2012.]

Filosofian lisensiaatti Inkeri Aula asuu ja työskentelee Turussa sekä tekee väitöskirjaa kulttuurintutkimuksen alalta Itä-Suomen yliopistoon. 